\title{
Auction Design Critical for Rescue Plan
}

\section{LAWRENCE M. AUSUBEL \& PETER CRAMTON}

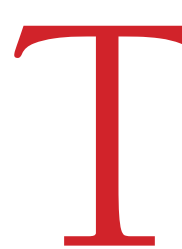

he Treasury proposes to invest $\$ 700$ billion in mortgage-related securities to resolve the financial crisis, using market mechanisms such as reverse auctions to determine prices. A well-designed auction process can indeed be an effective tool for acquiring distressed assets at minimum cost to the taxpayer. However, a simplistic process could lead to higher cost and fewer securities purchased. It is critical for the auction process to be designed carefully.

The immediate crisis is one of illiquidity. Banks hold a variety of mortgage-backed securities, some almost worthless while others

Lawrence M. Ausubel and Peter Cramton are Professors of Economics at the University of Maryland and experts in the theory and practice of auction design.

(c) The Berkeley Electronic Press retain considerable value. None can be sold, except at fire-sale prices. The Treasury proposes to restore liquidity by stepping in and purchasing these securities. But at what price?

\section{A SIMPLE APPROACH LEADS TO OVERPAYMENT}

A simple but naive approach would be to Ainvite the holders of all mortgage-related securities to bid in a single reverse auction. The Treasury sets an overall quantity of securities to be purchased. The auctioneer starts at a price of nearly 100 cents on the dollar. All holders of illiquid securities would presumably be happy to sell at nearly face value, so there would be excess supply. The auctioneer then progressively lowers the price-90 cents, 80 cents, etc.-and bidders indicate the securities that they are willing to sell at each lower price. Eventually, a price, perhaps
30 cents, is reached at which supply equals demand. The Treasury buys the securities offered at the clearing pricing, paying 30 cents on the dollar.

This simplistic approach is fatally flawed. The Treasury pays 30 cents on the dollar, purchasing all mortgage-related securities worth less than 30 cents on the dollar. Perhaps, on average, the purchased securities are worth 15 cents on the dollar. The Treasury buys only the worst of the worst, intervening in a way that rewards the least deserving. And, as a result of overpaying drastically, the Treasury can mop up relatively few distressed securities with its limited budget.

In the simplistic approach, competition among different securities overshadows competition within securities and among bidders. The auction merely identifies which securities

Economists' Voice www.bepress.com/ev September, 2008 
are least valuable, rather than determining the securities' value. An auction that determines a real price for a given security needs to require multiple holders of the security to compete with one another. This can be achieved if the Treasury purchases only some, not all, of any given security.

\section{A BETTER APPROACH}

Thus, a better approach would be for the

Ireasury to instead conduct a separate auction for each security and limit itself to buying perhaps $50 \%$ of the aggregate face value. Again, the auction starts at a high price and works its way down. If the security clears at 30 cents on the dollar, this means that the holders value it at 30 cents on the dollar. (If the value were only 15 cents, then most holders would supply $100 \%$ of their securities to be purchased at 30 cents, and the price would be pushed lower.) The auction then works as intended. The price is reasonably close to value. The "winners" are the bidders who value the asset the least and value liquidity the most.

This auction has an important additional benefit. The "losers" are not left high and dry. By determining the market clearing price, the auction increases liquidity for the remaining $50 \%$ of face value, as well as for related securities. The auction has effectively aggregated market information about the security's value. This price information is the essential ingredient needed to restore the secondary market for mortgage backed securities.

Handling many securities is a straightforward extension. Different but related securities can be grouped together in the same auction and purchased simultaneously. Each security has its own price. The bidders indicate the quantity of each security they would like to sell at the specified prices. The price is reduced for any security with excess supply and the process repeats until a clearing price is found for each security.

Auctioning many related securities simultaneously gives the bidders some flexibility to adjust positions as the market gradually clears. This improves price formation and enables bidders to better manage their liquidity needs. As a result, efficiency improves and taxpayer costs are further reduced.

For this auction design to work well, there needs to be sufficient competition. This should not be a problem for securities with diffuse ownership. For securities with more concentrated ownership, various approaches are possible. The Treasury could buy a smaller percentage of the face value. Alternatively, the Treasury could purchase the securities with the explicit understanding that the securities would be sold by auction some months or years in the future, after the liquidity crisis is over. To the extent that the securities are sold at a lower price, the holder would contractually owe the Treasury the difference, plus interest.

One sensible approach for the sequencing of auctions is to start with the best of the worst; that is, begin the auctioning with a group of securities that are among the least toxic. These will be easier for bidders to assess, and the auction can proceed more quickly. Then, subsequent auctions can move on to the increasingly problematic securities. In this way, the information revealed in the earlier auctions will facilitate the later auctions.

The basic auction approach suggested here is neither new nor untested. It was introduced over the last ten years and has been used successfully in many countries to auction tens of billions of dollars in electricity and gas contracts. It is quite similar to the approach that has been used to auction more than $\$ 100$ 
billion in mobile telephone spectrum worldwide. It is a dynamic version of the approach that financial markets use for share repurchases. If implemented correctly, each auction can be completed in less than one day.

Thus, the auction approach meets the three main requirements of the rescue plan: 1) provide a quick and effective means for the Treasury to purchase mortgage-related assets and increase liquidity; 2) yield prices that are closely related to value; and 3) provide a transparent rules-based mechanism that treats different security holders consistently and leaves minimal scope for discretion or favoritism.

Indeed, the second and third requirements may be decisive for obtaining broad political support. The main alternative to auctions put forward by the Treasury is to employ professional asset managers. To the extent that negotiations or other individualized trading arrangements are used, the public will be rightfully wary that favoritism may be exerted and that some security holders will be offered sweetheart deals. By contrast, a transparent auction process is readily subjected to oversight.

The Treasury appears to be embarking on the greatest public intervention into financial markets since the Great Depression. The ultimate success or failure of the intervention may depend on the fine details of the auction design. Let's get it right.

Letters commenting on this piece or others may be submitted at http://www.bepress.com/cgi/ submit.cgi? context=ev. 